\title{
Political Advertising and Propaganda Within Spiral of Silence-Agenda Setting Theory
}

\begin{abstract}
Hakan ALP
Istanbul University, Istanbul, Turkey

Political communication is an interactive process by which politicians transmit information and political discourse to voters and receive feedback through media. This communication process is a two way process of communication between politicians and voters by which, on the one hand, politicians transmit their thoughts and wills to voters, and on the other hand voters communicate their opinions to politicians, after interpreting, in different ways, the messages that they received. The key objective of political communication is to persuade or influence and cause voters, who are the target audience, to vote for a particular party by convincing them. In order to ensure the smooth operation of political communication processes it is essential that the parliament, government, political parties, non-governmental organizations, environmentalist groups and pressure groups also actually take part in this process. The decisive and transformative power of mass media and advertising phenomenon on the political systems has grown to become more and more influential in the recent years. The use of information considerably increases in line with the increase in the use of propaganda. No doubt, this information age has turned the world into "a universal village". On the one hand, the concentration in media and on the other hand rapid developments in Internet technologies expose societies to the bombardment of messages. Being exposed to or bombarded by numerous varieties of messages in their daily lives lead to the creation of variabilities and instabilities in individual's behaviors. Accordingly, political organizations while trying to convey messages to masses through political communication and advertising have to deliver systematic, comprehensible and influential messages by taking the advantage of visualization as much as possible.
\end{abstract}

Keyswords: political advertising, spiral of silence, agenda setting, communication

\section{Introduction}

Political communication is a concept closely related to democracy. Political communication began with the universal suffrage which means extension of the right to vote to masses and has come to have its present meaning as a result of the development and progress of mass media. The concept and practice of political communication was born and developed in the United States of America after the Second World War and began to be widely used in Western European countries in 1960s (Topuz, 1991, p. 7).

Political communication is an effort of communication, either one or two-way, made by a political view or political organ using the techniques of advertising, propaganda and public relations according to the requirements of the time and particular state of affairs on a continuous basisin the political system, in which it operates and carries out political activities, in order to build and maintain the trust, confidence and support of public opinion and accordingly to come to power. (Uslu, 1996, p. 790).

Hakan ALP, Ph.D., Institute of Social Sciences, Istanbul University. 


\section{Functions of Political Communication}

We can categorize the functions of political communication in terms of basic features as follows taking its functions into account:

(1) Transmission of political messages;

(2) Increasing the efficiency, duration, prevalence and persistence of messages;

(3) Measuring public opinion's expectations;

(4) Establishment of feedback channels and mechanisms;

(5) Exerting influence on opinion leaders;

(6) Improving ability to create and/or to set an agenda;

(7) Gaining an advantage over political rivals.

\section{History of Propaganda}

Propaganda is a means of political influence which seeks to influence opinions, or perspectives among a targeted audience and that should be considered together with the concept of having the power to govern a state or nation or community. It is a concept that is needed to be used for and considered together with the relationships based on self-interests and that arise as a consequence of prevailing inequalities between human societies.

It may also be regarded as an important tool for describing the power and demonstrating the exercise of the power in a political context for all domains of power. Propaganda has been a tool in all potential governmental environments and for all ruling bodies ranging from economic power relationships to political power and to different forms of religious power, employed for promulgating their opinions and wills and for persuading masses. We should note also note here that it is important that not to ignore the factstatues, sculptures, monuments, temples and places of worship, which are regarded as a manifestation of belief of polytheistic religions of ancient times, in which more than one god/goddess or force is worshipped, have a dimension associated with propaganda. Magnificent palaces and/or mausoleums of kings, pharaoh pyramids, divine temples of gods and goddesses, magnificent and gorgeous mosque and church buildings may, in a sense, be regarded as tools and areas of propaganda. Propaganda is essentially a tool that promotes and advertises power, however at the same time is also a demonstration or presentation of power. Consequently, buildings, squares, works of art, towers, monuments, divine temples and places of worship symbolizing power function as propaganda tool (Güngör, 2011, p. 295).

According to a different definition, propaganda is a communication activity aimed at influencing the attitude of public opinion and community towards a particular cause or position and to persuade and lead them to adopt a particular opinion or course of action and motivate and move them towards a particular direction (Çankaya, 2008, p. 19). Therefore, it is a process which requires a long-time planning, strategy, effort, patience and endeavors.

When we look at the concept of propaganda in terms of history, we can say that propaganda has a history that dates back to human history and those propaganda activities are as old as human history.

One implication of the term propaganda, when it was first used in the sociological sense by the Roman Catholic Church, "was to the spreading of ideas that would not occur naturally, but only via a cultivated or artificial generation" (Çiçek, 2007, p. 95). The concept of propaganda was solely used at all time by the church until the 18th century, when it had spread to general use. The term propaganda came to be widely used during 
the French Revolution and first became associated with politics in a real sense during the French revolution. Initial propaganda discourses and first propaganda officers emerged from revolutionary committees, revolutionary clubs and revolutionary parliaments (Bektaş, 2000, p. 146).

Human history is full of numerous examples of propaganda and communication from Roman legions marching battle to the sound of the drums to Egyptian pyramids reflecting the magnificence and glory of power and from Mongol barbarism destroying almost all cities they conquered and paralyzing all societies with fear to Christian cross which is seen as a representation of the crucifixion of Jesus and from magnificent palaces to symbols of crowns and symbols of empire. As a matter of fact, Ibn Khaldun yet in 1300s was writing as follows: "the sole purpose of using a large number of flags, increasing their colors and raising them so high is to put in hearths and there is no other reason for doing so" (Çankaya, 2008, p. 19).

On the other hand, in today's world we see that the term "propaganda" has acquired a strong negative connotation and is frequently used to define negative attributes. In particular, after the end of the 2nd World War, when it came to light that not only intelligence and propaganda agencies of the "opposite parties, enemies" used and/or posted lies and misleading information but also "our respective agencies as well as our fellows", led the term to be perceived negatively strongly being associated with lies and misleading information and to acquire a nasty and pejorative connotation.

\section{Propaganda and Image}

The creation of successful propaganda mainly depends on the creation of a successful image. There are three key elements of image making: Benett identified these three key elements as follows:

(1) preparation of a simple theme or message for the targeted audience, in other words message composition,

(2) dissemination of this message to all communication channels so that the message becomes salient and dominant among competing images, in other words to increase its quality and feature of standing out strongly and distinctly,

(3) surrounding the message with trappings of credibility in a manner to be accepted by the targeted audience, in other words to ensure the credibility of the message.

\section{Political Advertising and Propaganda}

Political advertising, which is one of the most widely used instruments, in particular during electoral periods, is a communication planned and implemented by a political party or candidate by purchasing advertising time and space in communication media and in various forms of media content such as radio and television to deliver political messages to influence the attitudes, behaviors and political beliefs of voters. An important point to be taken into account in the definition of political advertising is the fact that political advertisings are aired, broadcasted or published in any media in consideration of money or money's worth (Tokgöz, 2010, p. 172).

In the process of political advertising (campaign advertising) the direction of information flow is one way, that is to say that all information is held by and all messages are delivered by the focal person or groups who designed and created the advertising content or campaign. The power of political advertising to influence voters' opinions is directly proportional to the total media coverage in terms of time and space in the mainstream media. The capacity to purchase space in mass media including nationwide print media and radio and television networks that broadcast on a nation scale with high audience shares, rating points and leading market positions 
is directly proportional to the success of a political advertising. Accordingly, the process of political advertising is a process which is directly associated with power and at the same in contradiction with power. It can be said that political parties and politicians who are strong and powerful in economic sense design, develop and implement this process in an easy manner.

At the present time, political advertising has become such an essential and important element that cannot be ignored by political parties. In the first years in which it began to be used, political advertising was heavily focused on the introduction and promotion of the ideologies and programmes of political parties, however in the course of time has evolved into a trend in which the image of the leaders and candidates has come into prominence (Özkan, 2007, p. 22).

Political advertising, which is an important propaganda tool, aims to reach the target audience in the desired way and to influence them in the desired manner in accordance with political objectives by using advertising techniques. While, on the one hand, commercial advertising is typically designed to make consumers more aware of products, services or places seeking to increase interest in buying a product, visiting a place or using a specific service on the other hand advertising used by political groups is typically designed to deliver political discourses and messages to the target audience seeking their policies, programmes and opinions to be accepted by the target audience (Göker \& Alpman, 2010, p. 36).

Political parties use political advertising during electoral periods, and the presentation of the political party and candidates to the society (voters) focusing on their personal properties and areas of competence and specific talents and skills, and to stimulate voters' attention and interests for the election and candidates and to increase the support for the political party and/or candidates are the processes in which best efforts are used to take actions that would help advertisers to achieve their objectives.

It can be said that political advertising has drastically changed and its importance and influence began to highlighted as a means of gaining power and popularity in the United States of America after the Second World War with Dwight D. Eisenhower who was the first presidential candidate to run a series of paid spot commercials with political content on the television between 20 seconds and 60 seconds in the 1952 presidential elections of the United States of America (Tokgöz, 2010, p. 171).

Political groups generally prefer to implement political advertising during electoral periods in two different ways, namely, positive advertising and negative advertising. Negative political advertising, also known more colloquially as mudslinging involves an aggressive, one-sided assault designed to draw attention to the opponent party's and/or candidate's weaknesses in either position or character. In this type of advertising, in general, the elements of criticism remain in the forefront (Balci, 2006, p. 124). Negative political advertising which contain messages with ironic or sarcastic content in an explicit or implied manner generally highlights inconsistences in the promises made by the opponents or holds opponent candidates up to ridicule for involuntary or uncontrollable movements such as tongue twisters and speech defects or criticizes personal lives of opponents (Inal \& Karabağ, 2010, p. 43). On the other hand, positive political advertising is a form of communication by which the actions and performance of the political party or the candidate as well as their promises are presented to voters by setting an optimistic theme for the future. This type of advertising is designed and developed in a manner to highlight the candidate's or the party's good characteristic features (Balci \& Enes, 2007, p. 154). This type of positive advertising generally contains messages and and/or statements mentioning helpful actions performed by the political party or the candidate for the benefit of elderly people and/or disabled people, candidates' good relationships and affiliation with their families, financial and 
other assistance given to people in need by the candidates and other events occurred or contemplated and other characteristic features of candidates that would create a positive impression on voters (Inal Karabağ, 2010, p. 43).

\section{Agenda Setting in Political Propaganda Process and Spiral of Silence Theory}

One of the general behavioral patterns of human beings is the instinct of being on the side of the powerful. A number of various studies revealed that individuals, when developing an idea or thought, come together on opinions which are generally accepted and agreed to by the society. In other words, the individual's own opinions are shaped according to the society's general opinion.

Such behavioral pattern of adopting the opinion of the majority is typical for humans in many contexts and we come across this type of behavioral pattern not only in the political decision making process of individuals but also in many different contexts.

In the first place a world image is developed and created by means of mass media and subsequently mass media imposes on masses of people what to think about the image so created. In other words, the world to be considered and the issues to be thought about this world and ways of thinking are determined only by a handful of people.

The spiral of silence theory developed by Elisabeth Noelle-Neumann focuses on the fundamental socio-psychological thought arguing that the individualistic opinion depends on what others think. Neumann explains the basic pillars of the theory as follows:

(1) Society threatens deviant- radical individuals with isolation;

(2) Individuals at all times live with the fear of isolation;

(3) This fear of isolation causes individuals to try to constantly assess the climate of opinion through their personal relationships and through the media in order to maintain a high level of awareness concerning the social consensus;

(4) The outcomes of their perception of the climate of opinion affect individuals' behaviors and individuals will be willing or reluctant to speak out (Mcquail, 1997, p. 135).

According to the determinations made by Neumann, an individual prefers to remain silence either because of fear of isolation when the group or public realizes that the individual has a divergent opinion from the status quo or because of feeling/herself insecure and unsafe or prefers to obtain some benefits by standing on the side of the powerful. Apart from these individuals, there are also individuals who have not yet actually formed an opinion about the matter, in question and they are called indecisive segment of the population. Politicians, in particular, in electoral processes plan, design, develop and conduct their propaganda campaigns targeting this segment of the population. These indecisive individuals form the majority of the population in many societies. Accordingly, the primary target audience of political advertising and propaganda campaigns is these indecisive individuals.

If the voter believes that his/her opinion is among less dominant opinions he/she shall be less inclined to express his/her opinion. Eventually, opinions which are perceived to be dominant shall gain more importance and become more dominant whereas alternative opinions even further decrease.

For example, in the examination made by Neumann on thetendency of voters in Germany in the federal elections to be held in 1965, Neumann, in the first place found that the two major parties, namely, Christian Democrats and Social Democrats were in dead heat, and that there were indecisive voters, however that in the final weeks and days before the election, there had been "last-minute swing" whereby indecisive voters made 
their decision to vote for Christian Democrats upon publication of opinion polls and surveys in favor of Christian Democrats, and eventually Christian Democrats won the elections. This clearly shows the impact of the snowball theory and that there is a concentration on the party which is expected to win.

Politicians, while developing their propaganda and persuasion strategies, try to find the reasons behind the silence of individuals who prefer to remain silent and to reach them starting from this point of view based on such reasons and also try to convince them to form their decision making process in line with the expectations of politicians (Güngör, 2011, p. 299).

\section{Agenda Setting and Public Relations}

The model of agenda setting which is one of the ways to ensure that mass media to have an impact on and influence the society is based on the assumption that news reported on mass media plays an important role in shaping the opinions and positions of the members of the society, including shaping what people have to think and what people are interested in. Accordingly, this process turns into a strategy used by political actors and political parties in elections.

When the approach of agenda setting theory is evaluated with regard to political communication it is seen that there is a close association between the issues and matters in which voters are interested and content-form and size of headlines and spots used in mass media. In other words, one can mention about a tight association with the general tendency and agenda of common people and the agenda of mass media. When this process is considered from the viewpoint of influencing and persuading indecisive voters as mentioned earlier above, it can easily be seen that this is a serious process whereby indecisive voters are influenced and guided.

The method used by mainstream media in determining and presenting the content of news reported by them and headlines and photographs used and the length of the period of time that is used to publish and/or broadcast them and their area coverage have been gaining importance for the political party or candidates (Avci, 1990, p. 180).

Mainstream media in developing a public opinion or setting agenda uses and/or integrates various elements of communication in a holistic manner. In particular, columnists write their opinions, essays and their own version of the news by including their opinions in their stories in an insistent and target-oriented manner to influence and lead public opinion to adopt a certain policy or opinion. There is a relationship of signifier/signified between the media and those who are exposed to media messages.

Media is being used as a very important tool to direct politics and to change the state of affairs as well as agenda. The elements such as the space where news are placed in a newspaper, photographs used and the wording, genre and style used to write a news and the length of the news and headlines used are the clues indicating that in fact we are forced to form an opinion without even noticing it.

\section{Conclusion}

The histories of both public relations and advertising and propaganda date back to very old times. The form and manner of these concepts in political communication field have changed, evolved and developed in line with the development of means of mass communication and spreading of mass media.

The primary goal of the art and science of public relations is to develop mutual understanding and good faith of organizations, enterprises and companies in social context. On the other hand, the primary goal of propaganda is to shape the thoughts and opinions of individuals and to manage and guide their senses and 
conscious thought process for the sake of achieving the desired results

One of the common goals of political communication efforts is to make analysis of the behavioral patterns of voters and to provide political parties and candidates with the opportunity to review their strategies in accordance with the feedbacks received and in case of necessity to provide either or both of them with the opportunity to change their strategies. However, this process does not operate in the same manner as to the form of use by political parties their propaganda strategies. Political parties do not change their strategies in their propaganda processes based on feedbacks received. They insist on their tactics and strategies. Possibly, this is the most important feature that differs propaganda from public relations.

In democratic societies, media is considered as an institution that has acquired a well-deserved reputation as an impartial institution to allow public opinion to be freely formed and that audits the public administration. Media relations step in the third stage to make the implantation in accordance with the strategy developed in the planning stage following the stage of research conducted by public relations. The communication techniques an tools should be used in a more effective way in order to reach a wider audience.

At the present time, the media has also undertaken the mission of training and socialization between individuals apart from functioning as a mass media. Media plays a very crucial role as a determinant factor for cultural communication processes of societies. The right to freedom of thought and expression is an integral part of human rights and political election processes and when the right of society to information is taken into consideration, it is seen that the function of media in this direction is of paramount importance. This function of the media is adopted as a basic opinion by political parties and candidates who want to benefit from media in a positive sense in political life.

\section{References}

Avci, N. (1990). Illiteracy of informatics. Rehber Puslishing.

Balci, Ş. (2006). Negative political advertising in convincing message as fear attractiveness strategy use (Unpublished Doctoral Dissertation, Institute of Social Sciences, Selçuk University).

Bektaş, A. (2000). Public, communication and democracy (2nd ed.). İstanbul: Bağlam Publishing.

Çankaya, E. (2008). The power is under the cover. Ankara: Boyut Publishing.

Çiçek, C. (2007). Persuasion structure process, with the objective and methods. Konya: Tablet Publishing.

Eroğlu, A. H., \& Bayraktar, S. (2010). Voter preferences practices effects of political marketing-Izmir province example. Journal of Institute of Social Sciences, 12(2), 187-207.

Göker, G., \& Alpman, S. P. (2010). Political advertising as a ideological instrument on reproduction of power. E-Journal of New World Sciences Academy, I(5), 25-32.

Güngör, N. (2011). Communication theories, approaches. İstanbul: Politicial Publishing.

İnal, E. M., \& Karabağ, Ö. (2010). A comparative analysis of advertisements of political parties published in nigde local newspapers. IIBF Journal of Nigde University, 3(1), 41-56.

Mcquail, D. (1997). Mass communication models. İstanbul: İmge Publishing.

Özkan, N. (2007). Winning election campaigns (3rd ed.). İstanbul: MediaCat Publishing.

Özsoy, O. (1998). Methods and practices of propaganda and public opinion from the past to present. İstanbul: Alfa Publishing.

Tokgöz, O. (2010). Elections, political communication and political advertising. Ankara: İmge Publishing.

Topuz, H. (1991). Political advertising: Examples from around the world and in Turkey. İstanbul: Cem Publishing.

Uslu, Z. (1996). Political Communication and December 24th 1995 General Elections. Journal of New Turkey, 11, 790-804. 